\title{
Lokalna in regionalna samouprava $v$ Evropi in pri nas
}

\author{
UDK: 352 (497.12): $341.176(4)$ \\ Stane Vlaj \\ Univerza v Ljubljani, Fakulteta za upravo \\ stane.vlaj@fu.uni-lj.si
}

\section{IZVLEČEK}

Značilnosti današnje lokalne samouprave v Evropi sta dve: splošno soglasje o skupini splošnih vrednot in načel ter velika raznolikost institucij in praks. Evropska listina lokalne samouprave (MELLS) izpeljuje svoja splošna načela lokalne demokracije iz zgodovinske izkušnje držav, ki jih je preoblikovala v splošen vir in okvir. Načela MELLS se lahko uveljavijo $v$ različnih institucionalnih oblikah. Lokalna demokracija je eden od stebrov demokracije $v$ Evropi: načelo subsidiarnosti pa kaže stopnjo demokracije v neki državi.

Naraščajoča decentralizacija in devolucija odsevata splošno prisotno prepričanje, da so ekonomska rast, soobstojni razvoj, kakovostne javne službe in polna demokratična participacija državljanov učinkovitejši, če oblastne institucije niso vsesplošno centralizirane.

V demokratičnih državah je cilj lokalnih in regionalnih oblasti in države same pospeševati uresničevanje demokracije in zagotoviti najboljši možni odziv na potrebe ljudi. Za to mora obstajati sodelovanje med različnimi ravnmi oblasti ter med njimi in državljani. Na ta način se vzpostavlja potrebno ravnovesje med vsemi udeleženci dialoga. Če želi politični sistem doseči ustrezne rezultate, mora v procese odločanja vključevati vse, ki jih zadeva neka odločitev.

Pri reformi lokalne samouprave v RS je šlo za zlasti za zapostavljanje funkcionalne, finančne in regionalne sestavine. Zato je prišlo do skrajnosti, kot so: ustanovitev velikih in zelo majhnih občin, nastanek občin z ozkimi lokalnimi pristojnostmi iz prej preobremenjenih občin, centralizem namesto regionalizma itd. Vzrok za to pa je tudi v neuveljavljanju načela subsidiarnosti, kot ga pojmuje MELLS. V letu 2004 bo spremenjena Ustava RS tudi na področju lokalne samouprave. Novi člen 143 bo ustavna podlaga za ustanovitev pokrajin kot obvezne druge ravni lokalne samouprave v RS. Regije (pokrajine) bodo lahko učinkovitejše delovale kot partner evropskih strukturnih skladov ter $v$ prekomejnem regionalnem sodelovanju.

Ključne besede: lokalna samouprava, regionalizem, evropski standardi lokalne in regionalne samouprave, udeležba državljanov v lokalnem javnem življenju 


\section{Svet Evrope (SE) in evropski standardi lokalne in regionalne samouprave ${ }^{1}$}

\section{Uvod}

Lokalna samouprava je kazalec demokratičnosti neke države in po stališčih SE temeljni kamen vsake demokracije. Dokumenti SE (pa tudi EU) govore vse več o potrebi po krepitvi lokalne in regionalne demokracije, pri čemer $v$ ospredje postavljajo državljane, ki jim morajo biti predvsem namenjene vse dejavnosti $\vee$ lokalnih skupnostih. $^{2}$ Gre za kakovost njihovega življenja, za naravnanost javnih služb na njihove sodobne potrebe in interese. Lokalna demokracija je splet neposrednega odločanja prebivalcev in predstavniške demokracije. Če ni neposrednega odločanja prebivalcev na lokalni ravni, ni mogoče govoriti o lokalni samoupravi, ki je splet predstavniškega in neposrednega odločanja.

$\mathrm{SE}^{3}$ se od začetka ukvarja tudi z lokalno samoupravo (demokracijo), ki je temelj vsakega demokratičnega političnega sistema, in je od vseh evropskih institucij največ storil za razvoj lokalne samouprave $v$ Evropi. Najpomembnejši dokument, ki ga je sprejel na tem področju, je Evropska listina lokalne samouprave (MELLS). ${ }^{4}$ Listina je odločilno prispevala $k$ varstvu in povečanju splošnih evropskih vrednot in se je uporabljala tudi kot napotek za reforme lokalne demokracije $v$ državah srednje in vzhodne Evrope.

SE je 5. maja 1949 ustanovilo 10 zahodnoevropskih držav, danes pa je v njem včlanjenih 45 držav; sedež ima $v$ Strasbourgu. SE si prizadeva okrepiti sodelovanje držav članic na političnem, socialnem, pravnem in kulturnem področju $\vee$ Evropi ter varovati človeške pravice. Več kot 800 milijonov Evropejcev zastopajo vlade, parlamenti ter regionalne in lokalne skupnosti držav članic. Iz vlad se oblikuje Odbor

1 Slovenijo je kmalu po osamosvojitvi SE povabil k sodelovanju tudi na področju lokalne samouprave. Tako so njeni predstavniki s statusom opazovalcev že februarja 1992 sodelovali na prvi mednarodni konferenci o uresničevanju MELLS, ki jo je SE organiziral v Barceloni. Avtor je predstavljal RS v CDLR kot predstojnik Službe Vlade RS za lokalno samoupravo in strokovnjak za lokalno in regionalno samoupravo od 1992 do marca 2003.

2 SE pripravlja podrobno primerjalno študijo o obsegu in naravi pristojnosti lokalnih oblasti $v$ državah članicah (Preparation on detailed comparative study of the extent and nature of local authorities' responsibilities in Council of Europe member states, Committee of experts on the framework and structure of local and regional government, Strasbourg, 8. marec 2002).

3 Pri vključitvi RS v EU se ne sme pozabiti na SE in njegove dejavnosti na področju vzpostavljanja in krepitve lokalne in regionalne samouprave ( $v$ zadnjih letih še posebej poudarjene demokracije na teh dveh ravneh). RS je postala članica SE 1993, 1994 je podpisala MELLS, ki je najpomembnejši pravni dokument $v$ Evropi na tem področju, jo ratificirala 1996, $v$ celoti pa je zanjo začela veljati s 1. marcem 1997.

4 MELLS je v RS začela veljati 1. marca 1997, za njeno uresničevanje pa je pristojna Služba Vlade RS za lokalno samoupravo (zdaj Urad za lokalno samoupravo). Pripravljen pa je tudi osnutek svetovne listine lokalne samouprave, ki naj bi jo sprejela OZN in ki v bistvu razširja načela MELLS na ves svet. 


\section{Stane Vlaj}

\section{Lokalna in regionalna samouprava $v$ Evropi in pri nas}

(zunanjih) ministrov SE, iz parlamentov Parlamentarna skupščina SE, iz lokalnih in regionalnih oblasti pa Kongres lokalnih in regionalnih skupnosti Evrope (CLRAE). Organ odločanja je Odbor ministrov SE, glas demokracije Parlamentarna skupščina SE in glasnik lokalne demokracije CLRAE. SE si prizadeva doseči usklajevanje politik držav članic ter sprejemanje skupnih postopkov in norm. $V$ ta namen sklicuje sestanke parlamentarcev, vladnih izvedencev, lokalnih in regionalnih predstavnikov, mladinskih gibanj in mednarodnih nevladnih organizacij, ki tako lahko združijo svoje pristojnosti in izkušnje.

Med prednostnimi cilji SE sta tudi krepitev demokratičnih procesov in organiziranje sodelovanja na lokalni in regionalni ravni. ${ }^{\mathbf{5}}$

Tudi članstvo Slovenije $\vee$ EU bo imelo pomembne posledice za njeno lokalno samoupravo. EU se sicer neposredno ne spušča $\vee$ organizacijo oziroma strukturo lokalne samouprave $\vee$ posamezni državi članici, je pa vsekakor zelo zainteresirana za uveljavljanje skupnih evropskih standardov, kot so načelo subsidiarnosti, decentralizacija in opravljanje javnih storitev čim bližje državljanom.

Ministrske konference $\mathrm{SE}^{\mathbf{6}}$ sprejemajo resolucije in/ali sklepne izjave, ki so pomembna usmeritev za države članice pri uresničevanju MELLS.

Celovitejšo podobo delovanja SE na področju lokalne demokracije dobimo, če vštejemo tudi dejavnosti Parlamentarne skupščine SE in CLRAE, ${ }^{7}$ ki se prav tako ukvarjata z mnogimi zadevami v zvezi z lokalno demokracijo.

V zadnjih letih se SE osredotoča na vprašanja regionalizma v državah članicah, uresničevanja načela subsidiarnosti in z njim povezane decentralizacije, etike $v$ javnem upravljanju na lokalni ravni, udeležbe državljanov $v$ lokalnem javnem življenju, lokalnega menedžmenta, kriterijev za ustanovitev lokalnih in regionalnih

5 Predstavniki Slovenije redno sodelujejo $v$ delu Vodilnega odbora SE za lokalno in regionalno samoupravo (CDLR) ter njegovih pododborov in delovnih skupin za čezmejno sodelovanje lokalnih skupnosti, lokalne finance, položaj funkcionarjev in zaposlenih $v$ lokalnih upravah, za udeležbo državljanov $v$ lokalnem javnem življenju ter v pripravi dokumentov in gradiv SE na teh področjih. Predstavniki lokalnih skupnosti RS pa sodelujejo $v$ delu zbornice regij in zbornice lokalnih oblasti CLRAE. Tako kot druge države članice SE je tudi Slovenija pripravila uradni dokument o strukturi in dejavnosti svoje lokalne samouprave, ki ga je CDLR potrdil leta 1997. Urad za lokalno samoupravo pri MNZ redno obvešča generalnega sekretarja SE o zakonskih spremembah in predvidenih dejavnostih na področju lokalne samouprave.

6 Do sedaj jih je bilo 13, npr. Haag 1993 - Večja mesta in njihove periferije: Sodelovanje in koordinirano upravljanje; Lokalni referendumi; Varšava 1994 (neformalna konferenca) - Razvoj lokalne in regionalne demokracije v srednji in vzhodni Evropi; Lizbona 1996 - Lokalne finance; Carigrad 2000 - Lokalne socialne javne službe; Pakt stabilnosti za jugovzhodno Evropo - Vloga lokalnih in regionalnih skupnosti; Helsinki 2002 - obravnavala je vprašanja regionalizma in različnih rešitev tega vprašanja v državah članicah SE; Budimpešta 2004 - obravnavala bo dokument (konvencijo ali priporočilo) SE o regionalni samoupravi.

7 V okviru Pakta stabilnosti CLRAE daje pobude za partnerstvo in čezmejno sodelovanje lokalnih skupnosti, za sodelovanje mest s podobnimi problemi, za ustanavljanje agencij za lokalno demokracijo $v$ državah jugovzhodne Evrope, organizira usposabljanje lokalno izvoljenih predstavnikov in osebja $v$ lokalnih upravah idr. 
skupnosti idr. Sprejema vrsto priporočil, resolucij ministrskih konferenc o lokalni samoupravi, poročil in priporočil glede stanja na področju lokalne in regionalne demokracije v posamezni državi članici SE idr.

SE se sedaj ukvarja zlasti s temami, kot so dobra praksa $v$ finančnem in proračunskem upravljanju na lokalni in regionalni ravni; upravne in teritorialne reforme, ki ustvarjajo teritorialne skupnosti ali oblasti; obseg in narava pristojnosti lokalnih skupnosti; sosednja mesta, ki jih ločujejo mednarodne meje; dobra praksa glede javne etike na lokalni ravni; uporaba informacijske tehnologije na lokalni ravni; komunikacijska strategija CDLR (LOREG database, CDLR Internet site) ter priprava in izdajanje študij.

Program ADACS, ki je nasledil program LODE, nadaljuje podobne dejavnosti, kot so:

- pomoč pri pripravi zakonodaje s tega področja v posameznih državah;

- lokalne finance in fiskalna decentralizacija (FDI),

- usposabljanje osebja v lokalnih upravah;

- usposabljanje nacionalnih združenj lokalnih skupnosti za vlogo pogajalca z državo.

\section{Evropska listina lokalne samouprave (MELLS)}

Cilj MELLS je zagotoviti skupne evropske standarde za opredeljevanje in varovanje pravic lokalnih oblasti, ki pomenijo državljanom najbližjo raven uprave in jim omogočajo učinkovito udeležbo pri oblikovanju odločitev, ki se tičejo njihovega vsakdanjega okolja. Pravica državljanov, da sodelujejo pri opravljanju javnih zadev, se lahko najneposredneje uresničuje na lokalni ravni. Listina nalaga podpisnicam izpolnitev temeljnih pravil, ki zagotavljajo politično, upravno in finančno neodvisnost lokalnih skupnosti. Pripravljen pa je tudi osnutek svetovne listine lokalne samouprave, ki naj bi jo sprejela OZN in v bistvu razširja načela MELLS na ves svet.

Listina zavezuje podpisnice, da uporabljajo njena temeljna načela zato, da zagotovijo politične in zakonske razmere $v$ domačih pravnih sistemih za učinkovito lokalno demokracijo in še zlasti za konkretno izvajanje načela subsidiarnosti. Načelo subsidiarnosti je splošno načelo institucionalne organizacije, ki daje prednost bazi pred vrhom. To načelo je kriterij, ki zagotavlja spoštovanje demokracije in učinkovito opravljanje javnih zadev.

MELLS spoštuje veliko raznolikost političnih modelov teritorialne organizacije in lokalne samouprave $v$ različnih evropskih državah. Zavzema pa se za ustanavljanje takšnih lokalnih skupnosti, ki bodo sposobne $v$ zakonskih okvirih urejati in upravljati bistveni del javnih zadev z lastno odgovornostjo in $v$ korist lokalnega prebivalstva. Lokalne skupnosti naj bi imele splošno pristojnost za delovanje na vseh področjih, ki niso izključena iz njihove pristojnosti ali dodeljena drugim oblastem. 


\section{Stane Vlaj}

\section{Lokalna in regionalna samouprava $v$ Evropi in pri nas}

Področna zakonodaja konkretizira te naloge na posameznem področju ter natančen obseg pristojnosti države in lokalnih skupnosti. Pri tem je treba preprečiti dodeljevanje prevelikih pristojnosti lokalnim skupnostim brez finančnega kritja. Dodelitev pristojnosti eni ali drugi skupnosti mora upoštevati obseg in naravo javne zadeve ter zahteve učinkovitosti in racionalnosti.

\section{Regionalna samouprava ${ }^{8}$}

Svet Evrope sprejema temeljne pravne in politične dokumente $s$ področja lokalne in regionalne samouprave, Evropska unija pa računa z lokalnimi in regionalnimi oblastmi v posamezni državi, oblikovanimi po evropskih standardih. Načelo subsidiarnosti, ki ga priznavata obe organizaciji, pomeni tudi upoštevanje vloge in položaja lokalnih in regionalnih oblasti v posamezni državi s strani EU in posamezne države članice. Država ni več absolutno pristojna za določanje avtonomije svojih lokalnih in regionalnih skupnosti. Z ratifikacijo Evropske listine lokalne samouprave (MELLS) je tudi Slovenija prevzela mednarodno obveznost uresničevati v MELLS zapisana načela.

$\checkmark$ evropskih državah so glede regionalizacije velike razlike. Te je mogoče pripisati različnemu kulturnemu, zgodovinskemu, političnemu razvoju. Poznanih je naslednjih šest modelov regionalne samouprave:

- regije s pravico sprejemati primarno zakonodajo, kar jim zagotavlja ustava,

- regije s pravico sprejemati primarno zakonodajo, ki jim ni zagotovljena z ustavo,

- regije s pravico sprejemati zakonodajo $v$ skladu z načeli in splošnimi določbami nacionalne zakonodaje, ki jim jo zagotavlja ustava,

- regije s pravico sprejemati zakonodajo $v$ skladu z načeli in splošnimi določbami nacionalne zakonodaje, ki jim ni zagotovljena z ustavo,

- regije s pravico odločanja (brez zakonodajnega pooblastila) in s sveti, ki so neposredno izvoljeni,

- regije s pravico odločanja (brez zakonodajnega pooblastila) in s sveti, ki jih izvolijo lokalne oblasti.

\footnotetext{
8 Za besedo regionalizacija se skriva več pomenov. Ti so od dežele do dežele drugačni. Tako lahko regija pomeni različne in včasih prav raznovrstne institucionalne situacije. Lahko gre tudi za regionalne akcije, ki omogočajo razvoj države, lahko gre za regionalne javne zavode, ki so posebna oblika decentralizacije storitev, avtonomne sestavne dele regionalizirane države in včasih celo, če besede regija ne uporabljajo pravilno, za zvezno enoto. Regionalizem je pojav, ki je s procesom regionalizacije usmerjen h končnemu cilju - konstituiranju regij. Gre za sodoben pojav pri oblikovanju držav, kjer je na eni strani osrednja oblast, na drugi strani pa so lokalne skupnosti. Regionalizacija je proces, katerega cilj je izoblikovati regije, tj. ozemelj, ki jih družijo podobne ali celo enake značilnosti.
} 


\section{Stane Vlaj}

$\checkmark$ veljavni zakonodaji posameznih držav je mogoče zaslediti kriterije, ki se jih upošteva ob morebitnem spreminjanju meja, tudi ustanavljanju novih regij ${ }^{9}$ Svet Evrope regionalne oblasti definira kot oblasti, ki upravljajo območje (ozemlje) med državo in lokalnimi oblastmi. Čeprav so prakse tujih držav različne, zasledimo kot skupen cilj oziroma prizadevanje trend po večanju administrativne in finančne samostojnosti lokalnih skupnosti, večji demokratizaciji in uresničevanju načela subsidiarnosti.

$\mathrm{Na}$ lokalne in regionalne oblasti se najtesneje vežejo vprašanja, ki so povezana z uresničevanjem načel subsidiarnosti, decentralizacije in demokratizacije ter partnerstva in sodelovanja različnih ravni oblasti znotraj držav in $v$ mednarodnih povezavah.

Večina evropskih držav poudarja decentralizacijo, ustanavljajo se regije ali pa se daje dodatna avtonomija že obstoječim regijam. Načelo regionalne samoupra$v^{10}$ je povezano s spoštovanjem demokracije in z vidikom večjega povezovanja Evrope.

MELLS ni natančneje določila posebnosti regionalne samouprave. Uresničevanje načela subsidiarnosti in decentralizacije narekuje pripravo posebnega pravnega instrumenta SE tudi za to področje. ${ }^{11}$ Temeljna dilema pa je, kako konkreten in pravno zavezujoč naj bo ta dokument, in ali naj torej SE sprejme konvencijo (Evropsko listino o regionalni samoupravi) ali zgolj priporočilo. Za konvencijo se zavzema večina držav članic SE, CLRAE, Parlamentarna skupščina SE in Odbor regij pri EU. Prevladuje stališče, da naj bi bil tak dokument načelen in dovolj prožen

za uresničevanje regionalizacije $\vee$ skladu $z$ razmerami $\vee$ posamezni državi članici SE. ${ }^{12}$

9 Regionalizacija $v$ Italiji se je pričela leta 1948 kot posledica vrste zgodovinskih, geografskih, gospodarskih, kulturnih idr. razlogov. Italija je razdeljena na 8097 občin, 102 provinci in 20 regij, ki so avtonomna področja $z$ določenimi posebnostmi. Petnajst regij ima navaden status, pet pa posebnega. Italijanski zakon št. 142 o reformi krajevnih uprav iz leta 1990 v 16. členu navaja kriterije in usmeritve, katere se upošteva pri reviziji oziroma ustanavljanju novih provinc. Tako mora vsako njihjovo ozemlje ustrezati območju, na katerem se odvija večji del družbenih, gospodarskih in kulturnih odnosov prebivalcev. Obseg province mora po površini, št. prebivalcev in ekonomski moči omogočati načrtovanje takšnega razvoja, ki bo pospeševal gospodarsko, družbeno in kulturno ravnovesje na ravni province in regije. Območje posamezne občine mora $\checkmark$ celoti pripadati le eni provinci, število prebivalcev province ne sme biti manjše od 200.000 prebivalcev itd.

10 Regionalna samouprava, kjer pač obstaja, je del demokratičnega upravljanja, zato morajo regionalne oblasti imeti minimalne standarde demokratične zgradbe in biti opremljene z zakonskimi pristojnostmi in zmožnostjo znotraj ustavnih in zakonskih okvirov urejati in upravljati del javnih zadev s svojo odgovornostjo $v$ interesu prebivalcev in $v$ skladu z načelom subsidiarnosti. 11 Osnutek evropske listine o regionalni samoupravi pravi, da je regija bistveni sestavni del države, eden od temeljev demokratičnega režima in primerna raven oblasti za učinkovito uresničevanje subsidiarnosti, da ponazarja raznovrstnost Evrope, pri čemer mora spoštovati lokalno (občinsko) avtonomijo.

12 Priporočilo je lahko politično še bolj zavezujoče za članice SE, saj se nanaša na vse članice, konvencija pa je dokument, ki bi ga posamezne članice podpisale in ratificirale ali pa ne. Poleg tega bi imela tako kot MELLS obvezni in neobvezni del. 


\section{Stane Vlaj}

\section{Lokalna in regionalna samouprava $v$ Evropi in pri nas}

Slovenija se zavzema za sprejem pravnega dokumenta SE o regionalni samoupravi v obliki konvencije. ${ }^{13}$ Pri tem tudi mi poudarjamo, da mora biti dokument fleksibilen oz. takšen, da bo spoštoval različnost razmer $\vee$ državah članicah SE ter omogočal široko možnost izbire na tem področju. Za RS je bil že osnutek evropske listine o regionalni samoupravi koristna smernica pri pripravah ustavnih sprememb, ki jih potrebujemo za uvedbo pokrajin, zakona o pokrajinah ter drugih dokumentov, ki se nanašajo na nadaljnji razvoj lokalne in regionalne samouprave pri nas.

13. konferenca evropskih ministrov, odgovornih za lokalno in regionalno samoupravo, je bila 27. in 28. junija 2002 v Helsinkih na Finskem. ${ }^{14}$ Obravnavala je dve temi: »Regionalna samouprava in subsidiarnost - evropski modeli in načela" in »Regionalna samouprava in subsidiarnost - podrobna obravnava besedil, ki jih je pripravil Vodilni odbor SE za lokalno in regionalno demokracijo (CDLR) «. ${ }^{15}$ Ministri so v okviru prve teme izmenjali izkušnje in poglede glede regionalne samouprave, regionalizacije, decentralizacije in uresničevanja načela subsidiarnosti. Ministri so se strinjali, da je delujoča demokracija temelj miru, stabilnosti, napredka in razvoja. Naraščajoča decentralizacija in devolucija odsevata splošno prepričanje, da se ekonomska rast, soobstojna obnovitev, kakovostne javne službe in polna demokratična participacija učinkoviteje razvijajo, če oblastne institucije niso vsesplošno centralizirane. Seveda je stvar vsake države, da odloči, ali bo ustanovila regionalne oblasti, ki jih dejansko nimajo vse države. SE pri tem igra pomembno vlogo pri podpori učinkovite demokracije $\vee$ vseh državah članicah tako na državni kot na poddržavni ravni. ${ }^{\mathbf{1 6}}$

13 Tak pravni dokument naj bi spoštoval suverenost, identiteto in svobodo držav, da določajo svojo notranjo organizacijo z upoštevanjem teh splošnih načel. Bil naj bi dovolj širok, da bi priznal široko lestvico demokratičnih oblik regionalne samouprave. Jasen mora biti $v$ tem, da ima vsaka država pravico odločiti se, ali bo uvedla regionalne oblasti ali ne. Dokument ne sme ogroziti načela enakopravnosti lokalnih in regionalnih oblasti in njihove avtonomije, kjer je to načelo uveljavljeno z ustavo ali zakonom. Tudi ne sme voditi $h$ kreaciji relativnih vrednot med različnimi modeli regionalne avtonomije. Države morajo imeti izbiro, ki jim omogoča upoštevanje specifičnih karakteristik njihovega sistema regionalne samouprave. Dokument naj bi bil v harmoničnem skladju z MELLS.

14 Conference of European ministers responsible for local and regional government, 13th Session, Helsinki, 27. in 28. junij 2002, Helsinki Declaration on Regional Self-Government. 15 Po mnenju CDLR je pet področij, ki bi jih urejal dokument SE o regionalni samoupravi, potencialno sprejemljivih za vse države članice: odgovornosti oz. pristojnosti regionalnih oblasti; notranja struktura - regionalni organi; finančni in človeški viri regionalnih oblasti; varstvo regionalne samouprave; nadzor dela regionalnih oblasti.

16 Ministri so izrazili mnenje, da bi moral imeti SE cilj sprejeti pravni dokument o regionalni samoupravi na temeljnih konceptih in načelih, ki jih je že pripravil CDLR. Dokument naj bi bil v harmoničnem skladju z MELLS. Odboru ministrov SE ministri priporočajo, da razvija in okrepi delo SE na področju lokalne in regionalne samouprave, vključno s promocijo izkušenj na področju regionalne samouprave. Nadaljuje naj se dialog na evropski ravni med vladami ter lokalnimi in regionalnimi izvoljenimi predstavniki, zbranimi v CLRAE. CDLR naj se naloži, da izdela osnutke za pravni dokument različnih vrst in pri tem upošteva predloge konference, izkušnje članic in ustrezno razmerje do MELLS. K izjavi je priložen dodatek "Core concepts and common principles on regional self-government identified by the CDLR«. 
Konvencija ne želi zavezovati evropskih držav, naj ustanovijo regionalne ravni oblasti. Vsaka država je avtonomna pri odločanju o svoji oblastni strukturi. Na to ves čas opozarjajo tako pristaši listine kot njeni nasprotniki. Zbornica regij CLRAE je na junijskem zasedanju sprejela resolucijo, ki podpira pravni dokument o regionalni samoupravi v obliki konvencije. Tak dokument je podprl tudi Odbor CLRAE za kmetijstvo in okolje, ki je pristojen tudi za lokalno in regionalno demokracijo. CLRAE poudarja, da konvencija kot pravni dokument ne zahteva, da država ustanovi regije, vendar bo njen sprejem okrepil regionalno demokracijo. $V$ Evropi so uveljavljeni različni modeli regionalizacij, države pa se same odločajo, kateri jim ustreza in kateri ne. Nekatere države regij sploh ne potrebujejo. Regionalizacija za države ni obvezna, listine ni treba podpisati in ratificirati, podpisnice pa si bodo lahko pridržale tudi nekatere rezervacije, kot to velja za MELLS.

Zaključni dokument helsinške konference poudarja, da bo SE priznal in promoviral splošna načela regionalne samouprave $v$ evropskem pravnem dokumentu, $v$ katerem bodo upoštevane izkušnje držav članic. O tem bo ponovna razprava na 14 . Evropski konferenci ministrov, pristojnih za lokalno in regionalno samoupravo, ki bo leta 2005 v Budimpešti.

\section{Čezmejno sodelovanje lokalnih in regionalnih skupnosti}

Maja 1980 so države članice SE v Madridu podpisale Evropsko okvirno konvencijo o čezmejnem sodelovanju teritorialnih skupnosti ali oblasti, ${ }^{17}$ s katero so se zavezale, da bodo omogočale in spodbujale obmejno sodelovanje med lokalnimi skupnostmi, ki so pod njihovo sodno pristojnostjo, ter si prizadevale za sklenitev ustreznih sporazumov in dogovorov. Konvencija šteje za obmejno sodelovanje vsak dogovor, s katerim se krepijo in razvijajo sosedski odnosi med lokalnimi skupnostmi, kot tudi vsak sporazum, sklenjen $v$ ta namen.

Čezmejno sodelovanje se nanaša predvsem na okolje, javne službe, razvoj, prevoz in skupne naprave. Pogoji zanj pa so:

- resnična lokalna samouprava,

- pozitivna politična volja,

- ustrezen pravni okvir,

- politična volja, da se odpravijo ovire, in

- evropska vizija.

$\checkmark$ konvenciji je poudarjeno, da se obmejno sodelovanje izvaja $\vee$ okviru pristojnosti lokalnih skupnosti, opredeljenih v notranji zakonodaji. Dogovori in sporazumi lokalnih skupnosti se lahko zgledujejo po vzorčnih in okvirnih sporazumih, statutih in

17 Okvirno konvencijo o čezmejnem sodelovanju teritorialnih skupnosti ali oblasti je RS podpisala 21. maja 1980, dodatni protokol 9. novembra 1995 in protokol št. 2 5. maja 1998. Konvencija je bila ratificirara v letu 2003. 


\section{Stane Vlaj}

\section{Lokalna in regionalna samouprava $v$ Evropi in pri nas}

pogodbah, ki so priloženi tej konvenciji. Države pogodbenice lahko sklepajo tudi meddržavne sporazume, ki med drugim lahko določajo okvir, oblike in omejitve za obmejno sodelovanje lokalnih skupnosti. Konvencija je sploh naravnana tako, da se sporazumi in dogovori sklepajo ob popolnem spoštovanju določb notranje zakonodaje vsake pogodbenice.

Pri čezmejnem sodelovanju gre za proces; veliko je dela z vizumi, odpravo različnih ovir in vzpostavitvijo ustrezne infrastrukture. EU, ki sicer že leta prispeva $h$ krepitvi čezmejnega sodelovanja, naj bi bolj koordinirala svoje dejavnosti s SE in nasprotno, kar bo prispevalo $\mathrm{k}$ boljšim rezultatom prizadevanj obeh.

Lokalne in regionalne skupnosti imajo nepogrešljivo vlogo pri krepitvi demokratične stabilnosti $\vee$ Evropi. Še zlasti pa je $\vee$ zadnjem času poudarjena krepitev čezmejnega sodelovanja med lokalnimi skupnostmi na področju kulture, ${ }^{\mathbf{1 8}}$ saj to krepi medsebojno razumevanje in zaupanje med ljudmi, ki živijo na obeh straneh meje, ne glede na to, ali imajo skupen jezik, religijo in kulturno dediščino.

Konvencijo je podpisala in leta 2003 ratificirala tudi RS. Dosedanje izkušnje čezmejnega sodelovanja Slovenije s sosednjimi državami so zelo dobre. Pri skupnem sodelovanju z Italijo, Avstrijo in Madžarsko je bilo pripravljenih več kot 100 projektov s področij prometa in obmejne infrastrukture, okolja, turizma, kmetijstva, drobnega gospodarstva, kulture in človeških virov. ${ }^{19}$

Pripravljen je bil tudi predlog projektov za čezmejno sodelovanje med Republiko Slovenijo in Republiko Hrvaško. ${ }^{20}$ Gre za projekte, ki se nanašajo na prometno in obmejno infrastrukturo, okolje in varstvo narave, gospodarsko sodelovanje ter regionalne in lokalne pobude.

Eden glavnih problemov našega čezmejnega sodelovanja je $v$ tem, da naš sedanji upravni sistem ni primerljiv s sosednjimi državami. Zaradi odsotnosti regionalne ravni se moramo bolj potruditi za obvladovanje čezmejnega sodelovanja in vzdrževanje ravni, kakršno imajo sosednje države. To pomeni, da trenutno še nimamo $v$ celoti organizirane javne infrastrukture, ki bi na vseh ravneh celovito podpirala vzpostavljanje ali širjenje stikov in sodelovanja. Predvsem nam manjkajo tiste regionalne strukture, ki bi povezovale, motivirale, usmerjale in podpirale izvajanje skupnih projektov, s tem pa seveda tudi organizirane animacijske dejavnosti, ki bi pomenile priložnost za skupni razvoj, zaradi česar na nekaterih področjih prihaja do nerazumevanja in tudi odpora zaradi strahu pred konkurenco. Težave imamo tudi pri

18 Draft Recommendation on Fostering Transfrontier Co-operation between Territorial Communities or Authorities in the Cultural field, Steering Committee on Local and Regional Democracy, Strasbourg, 6. maj 1999.

19 Podrobno o tem dr. Riana Benko, Programi pomoči Evropske unije, Inštitut za prenos znanja in tehnologije, Ljubljana 1999.

20 Predlog projektov za čezmejno sodelovanje med Republiko Slovenijo in Republiko Hrvaško, Služba Vlade RS za evropske zadeve, Ljubljana, 24. 12. 1999. 


\section{Lokalna in regionalna samouprava $v$ Evropi in pri nas}

zagotavljanju lokalnih finančnih virov, ker posamezne občine finančno niso dovolj močne.

\section{Javna etika na lokalni ravni}

Med prioritetami SE na področju poglabljanja lokalne in regionalne samouprave je tudi javna etika na lokalni ravni, povezana z bojem zoper korupcijo in druge oblike finančnega kriminala v lokalnih organih. Skupini specialistov je CDLR zaupal nalogo, da pripravi zbirko oz. priročnik dobrih praks na tem področju.

Skupina specialistov je tematiko razdelila na šest podtem, in sicer:

- statut in pravila, ki veljajo za odgovornost lokalno izvoljenih predstavnikov (jamstva, odobritve, profesionalno varstvo, civilna, kazenska in upravna odgovornost idr.);

- status lokalnih javnih uslužbencev in pravila službe (pogoji za imenovanje in odpust, diskvalifikacije, odgovornosti, obveznosti do izvoljenih predstavnikov idr.);

- razpoložljiva sredstva za izvajanje lokalne demokracije $v$ praksi (financiranje volilne kampanje, financiranje političnih združenj in strank na lokalni ravni idr.);

- dostop do informacij, upravna preglednost in upravni postopki;

- nadzor in računovodski postopki;

- razmerja med lokalnimi oblastmi in zasebnim sektorjem (pogodbe o javnih naročilih, pomoč in drugi finančni prenosi osebam zasebnega prava, profitnim in neprofitnim, gospodarske agencije, ki pripadajo občini, izdajanje dovoljenj in certifikatov).

Na tej podlagi in na podlagi drugih razpoložljivih informacij (zlasti priporočil Odbora ministrov SE) je sekretariat pripravil šest tematskih dosjejev, ki vsebujejo tudi seznam priporočil za različne skupnosti in vključene ljudi (centralne in lokalne oblasti, izvoljene predstavnike, kandidate in politične vodje); ti dosjeji sestavljajo prvi del priročnika.

Priročnik je zdaj $\vee$ osnutku pripravljen ${ }^{\mathbf{2 1}}$ in je dostopen na spletnih straneh SE: www.coe.int/local ali www.loreg.org. Priročnik naj bi postal realen praktičen instrument za države in lokalne ter regionalne oblasti.

Na zadnji seji CDLR novembra 2002 v Strasbourgu je bilo dogovorjeno, da naj člani CDLR (vladni strokovnjaki iz držav članic SE) za promocijo tega nadvse pomembnega priročnika organizirajo nacionalna posvetovanja $\vee$ različnih oblikah: prevod in posredovanje priročnika združenjem lokalnih in regionalnih oblasti in lokalno in regionalno izvoljenim predstavnikom; organizacija srečanj z lokalnimi in

21 Public ethics at local level, Model initiatives package, CDLR, Strasbourg, 13. januar 2003. 


\section{Stane Vlaj}

\section{Lokalna in regionalna samouprava $v$ Evropi in pri nas}

regionalnimi funkcionarji in uradniki iz lokalnih in regionalnih uprav; organizacija seminarjev, delavnic ali nacionalnih konferenc (po potrebi s pomočjo članov sekretariata in strokovnjakov ter finančno udeležbo SE); objava priročnika na vladnih spletnih straneh z možnostjo dajanja komentarjev javnosti. Te dejavnosti naj bi bile zaključene do novembra 2003, vsaka članica SE pa bo morala pripraviti poročilo o rezultatih razprave o priročniku.

Nizozemska vlada bo spomladi 2004 gostila mednarodno konferenco o rezultatih obravnave priročnika $v$ državah članicah $S E$, drugih telesih $S E$, nevladnih organizacijah, EU, OECD, Svetovni banki ipd., ta pa bo nato dopolnjen in sprejet v končni vsebini. Na konferenci naj bi s političnega vidika obravnavali zlasti financiranje političnih strank, kandidatov, volitev, samozavarovanje javnih uslužbencev, omejitve daril, integriteto političnih in izvoljenih predstavnikov ter finančni nadzor, sodelovali pa naj bi predstavniki lokalnih in regionalnih oblasti, njihova združenja, ministri, državni sekretarji, različna civilna združenja in drugi.

Priročnik spremljajo še avtorski prispevki o statusu lokalnih javnih uslužbencev in pogojih za njihovo delo (Češka), razpoložljivih sredstvih za uresničevanje lokalne demokracije $\vee$ praksi (Finska), notranji in zunanji kontroli (Francija), dostopu do informacij, upravni preglednosti in upravnih postopkih (Italija), statusu in pravilih za verodostojnost lokalno izvoljenih predstavnikov (Združeno kraljestvo), strukturah, ki so urejene z zasebnim pravom, case studies (načela javnega življenja, primer modela pobude na področju zasebnopravnih podjetij z javnim kapitalom) ter izjave izvoljenih oseb o financiranju lokalnih volitev (primer Helsinkov).

Lokalne oblasti so v celoti odgovorne za svoje upravljanje volilnemu telesu, javnemu mnenju, upravnim ali civilnim sodiščem ali ( $v$ nekaterih primerih) kazenskim sodiščem. Vzpostaviti morajo posebni strokovni notranji kontrolni mehanizem, da bi kar se da omejile tveganje:

- slabega ekonomskega ali finančnega upravljanja;

- slabega upravnega menedžmenta, ki izvira iz nespoštovanja pravil;

- revne oskrbe s storitvami;

- upravnega, civilnega ali kazenskega postopka.

\section{Dialog med oblastmi in državljani}

Naraščajoči proces decentralizacije, krepitev demokracije in sistem novega upravljanja zahtevajo nove sofisticirane mehanizme dialoga med državo, regionalnimi in lokalnimi skupnostmi, njihovimi združenji ter državljani. V marsikateri državi ugotavljajo, da so se začele zelo pomembne spremembe, ki vodijo $v$ nova razmerja med ravnmi oblasti. Nastopili so izzivi novih realnosti, prelom $s$ preteklostjo, nove finančne ureditve, naraščajoče vključevanje poddržavnih ravni oblasti v vladanje in upravljanje ter pritisk državljanov, ki se vse bolj zavedajo svojih pravic in potreb. 


\section{Stane Vlaj}

$\checkmark$ demokratičnih državah je cilj lokalnih in regionalnih oblasti in države same pospeševati uresničevanje demokracije in zagotoviti najboljše možne zadovoljitve potreb ljudi $\vee$ danih razmerah. Da bi to dosegli, mora obstajati sodelovanje med različnimi ravnmi oblasti, konflikti pa se morajo reševati z vidika doseganja omenjenih ciljev. Ko razpravljamo o lokalni in regionalni demokraciji, morata vedno biti v ospredju državljan in kakovost njegovega življenja.

Kompleksnost modernih družb zahteva stalen dialog med vsemi ravnmi oblasti in državljani, ${ }^{\mathbf{2 2}}$ čeprav obstajajo različna gledišča, ${ }^{\mathbf{2 3}} \mathrm{s}$ katerih naj bi analizirali razmerje med participacijo in demokracijo, obstaja mnogo vzrokov, ki spodbujajo udeležbo. Javna telesa dobijo zahtevano legitimnost, sredstva za učinkovito odločanje in podporo državljanov za doseganje posebnih ciljev. Državljani pa sodelujejo, če se jim zdi, da je zadeva dovolj zanimiva in da se splača sodelovati. Za udeležbo državljanov $\vee$ lokalni politiki je mnogo razlogov: praktični razlogi, izrecna ali posvetovalna udeležba ali pa zgolj državljanska dolžnost. $\vee$ instrumentalnem pogledu pa udeležbo lahko jemljemo kot pot posameznikov, da dosežejo svoje cilje.

Institucionalni dialog $v$ enotni (unitarni) državi lahko opišemo kot celotno mrežo komunikacijskih razmerij med centralno oblastjo na eni strani in drugimi ravnmi teritorialnih oblasti na drugi strani. $V$ zadnjih desetletjih ta dialog postaja vse pomembnejši strateški faktor $v$ državah zaradi naraščajoče kompleksnosti upravljanja in prizadevanja, da bi javne zadeve opravljale tiste oblasti, ki so bližje državljanom. Institucionalni dialog je tako bistveni del upravljanja $\vee$ moderni državi. Prelom s preteklostjo, zahteve novih realnosti, nove rešitve, nove finančne ureditve, vključevanje poddržavnih ravni $v$ oblastne in upravne dejavnosti ter pritisk državljanov, ki se vse bolj zavedajo svojih pravic in potreb, so pomembne novosti, ki se jim moramo posvetiti z akademskim in praktičnim pristopom. ${ }^{\mathbf{2 4}}$ Institucionalni dialog poteka po načelih učinkovitosti, preglednosti in racionalnosti. Ta terjajo zagotovitev vseh relevantnih informacij vsem udeležencem, jasna pravila, čimprejšnjo predstavitev rezultatov dialoga javnosti, pristojne (izvoljene) organe, dobro koordinacijo idr. Takšen dialog je bistveni del upravljanja demokratične države.

Naraščajoči proces decentralizacije, krepitev demokracije in sistem novega upravljanja zahteva nove, sofisticirane mehanizme dialoga med državo, regionalnimi

22 Regionalne in lokalne oblasti se vse bolj vključujejo $v$ zadeve, ki so bile tradicionalno $v$ izključni domeni državnih oblasti. Ta 'lokalizacija' državnih problemov je neposredna posledica novih upravljalskih procesov, načela subsidiarnosti in okrepitve mehanizmov verodostojnosti.

$23 \mathrm{Na}$ primer realistično stališče, po katerem je namen politike izražati in braniti interese, namen udeležbe državljanov pa je doseči te cilje in zagotoviti optimalne rezultate z minimalnimi stroški. Drugo stališče je povsem nasprotno. Po njem je demokracija proces, ki potrebuje maksimalno udeležbo državljanov. Tretje stališče temelji na zahtevi izključenih skupin, da se vključijo $v$ procese odločanja. Zagovorniki posvetovalne demokracije pa želijo, da državljani lahko vzpostavijo razmerja s političnimi institucijami, tudi na neinstitucionalen način.

24 Preliminary draft report on "Institutional dialogue between the state, regions, local authorities and their associations", Steering Committee on Local and Regional Democracy (CDLR), Strasbourg, 8. april 2002, str. 4. 


\section{Stane Vlaj}

\section{Lokalna in regionalna samouprava $v$ Evropi in pri nas}

in lokalnimi skupnostmi, njihovimi združenji ter državljani. Ta razmerja, ki zajemajo vse dejavnosti med različnimi teritorialnimi enotami vseh tipov in na vseh ravneh, so nova razsežnost javne politike. Obstaja veliko različnih oblik institucionalnega dialoga. Največkrat so to skupna telesa, v katerih imajo svoje predstavnike vse udeležene ravni oblasti, ali pa skupni sestanki, konference, delavnice idr. ${ }^{\mathbf{2 5}}$

\section{Udeležba državljanov v lokalnem javnem življenju ${ }^{26}$}

Izziv je ustvariti sisteme lokalne demokracije, v kateri imajo državljani možnost participacije. Glavne točke so odprte tako na strani institucij kot na strani državljanov, ki naj imajo možnost vplivati na odločitve, če čutijo potrebo za to. Vse države upajo, da bodo njihovi sistemi lokalne demokracije prispevali k naraščajoči participaciji različnih socialnih in gospodarskih skupin ter vodili k bolj posvetovalni politiki, ki bo konsolidirala mnoge interese $v$ iskanju splošne vizije in partnerstva za kolektivno akcijo.

Sodelovanje državljanov je srce demokracije. Državljani, ki spoštujejo demokratične vrednote in ki se zavedajo svojih državljanskih dolžnosti ter vključujejo v politično dogajanje, so življenjska sila vsakega demokratičnega sistema. SE pripravlja novo študijo o razmerju med velikostjo lokalnih skupnosti, njihovo učinkovitostjo in vključenostjo državljanov v lokalno politiko.

Udeležba državljanov $\vee$ javnem življenju njihovih lokalnih skupnosti je značilnost demokracije. Nizka stopnja udeležbe $\vee$ demokratičnem procesu je skrb zbujajoč znak in dejavnik, ki prizadeva delovanje lokalne demokracije. ${ }^{27}$ Čeprav

2521 držav članic SE je odgovorilo na vprašalnik CDLR o različnih modalitetah institucionalnega dialoga v njihovem primeru. Odgovori so dostopni na Local Democracy Website (www.coe.int. pod "Legal«).

26 Recommendation Rec (2001) 19 of the Committee of Ministers to member states on the participation of citizens in local public life, 6. december 2001.

27 "Udeležba državljanov pa ni samo splošen problem. Ima tudi specifične razsežnosti, ki ustrezajo različnim zmožnostim za prispevanje različnih sociogospodarskih skupin. Ženske, mladi ljudje, etnične skupine, starejši in prizadeti ljudje so skoraj v vseh državah skupine, ki so premalo udeležene zlasti v predstavniških institucijah lokalne demokracije.

Biti je treba pozoren na tiste kategorije državljanov, ki se teže aktivno vključujejo in ki dejansko ostajajo na obrobju lokalnega javnega življenja.

Zavedati se je treba, da je pomembno, da so ženske enakopravno zastopane v lokalni politiki.

Zavedati se je treba, da so otroci in mladina potencial za trajno uravnotežen razvoj lokalnih skupnosti, in poudariti vlogo, ki jo lahko imajo.

Priznati in povečati je treba vlogo, ki jo imajo združenja in skupine državljanov kot ključni partnerji pri razvijanju in ohranjanju kulture sodelovanja in kot gonilna sila pri demokratičnem sodelovanju v praksi ...

Za tujce posebej velja, da se spodbuja njihovo aktivno sodelovanje v življenju lokalne skupnosti, in sicer brez diskriminacij in v skladu z določili Konvencije o sodelovanju tujcev v javnem življenju na lokalni ravni Sveta Evrope iz leta 1992, tudi kadar ta določila niso zakonsko obvezujoča za države, ali pa naj vsaj črpajo pobude iz mehanizmov, na katere se sklicuje ta konvencija. Priporočilo Rec (2001) 19 Odbora ministrov SE državam članicam o sodelovanju državljanov v lokalnem javnem življenju. 
obstajajo različna gledišča ${ }^{\mathbf{2 8}}, \mathrm{s}$ katerih naj bi analizirali razmerje med participacijo in demokracijo, obstaja mnogo vzrokov. ki spodbujajo udeležbo. Javna telesa dobe zahtevano legitimnost, sredstva za učinkovito odločanje, podporo državljanov za doseganje posebnih ciljev. Državljani pa sodelujejo, če vidijo dovolj zanimivo zadevo, pri kateri se splača sodelovati idr. Obstaja mnogo razlogov, ki spodbujajo državljane k udeležbi v lokalni politiki. Sledijo praktičnim razlogom, izrecni ali posvetovalni udeležbi, ali zgolj državljanski dolžnosti. $\vee$ instrumentalnem pogledu pa udeležbo lahko jemljemo kot pot posameznikov, da dosežejo svoje cilje.

Vendar pa večina državljanov ostaja pasivna oziroma nezainteresirana. Pri tem nekateri mislijo, da ta apatija izvira iz nizke ravni interesa, drugi pa, da odseva njihovo neustrezno politično moč. Tisti, ki zagovarjajo udeležbo, menijo, da ta izraža skrb za skupnost, ki ji pripadajo državljani, in državljanom omogoča učiti se umetnosti državljanstva. $\vee$ modernem času se zdi ta ideja preveč romantična.

Uvedba lokalne samouprave $\vee$ RS je imela za cilj tudi demokratizacijo življenja ljudi $v$ lokalnih skupnostih $z$ večjo uporabo zborov občanov, kot je danes, lokalnih referendumov, državljanske iniciative in drugih oblik vključevanja ljudi $\vee$ procese odločanja v lokalni skupnosti. S temi oblikami naj bi ugotavljali odnos ljudi do konkretnih in perečih težav, ki jih čutijo $v$ svoji lokalni skupnosti. Udeležba državljanov v najrazličnejših oblikah je značilna $v$ vseh državah z razvito lokalno samoupravo. Pri nas so te oblike precej zanemarjene in zato nerazvite. Boljše so razmere $v$ manjših, podeželskih občinah.

\section{Lokalna samouprava v Sloveniji ${ }^{29}$}

\section{Ustavna in zakonska podlaga}

Osamosvojitev Slovenije kot države in uvedba parlamentarne demokracije $v$ letu 1991 sta pomenili nov začetek tudi za lokalno samoupravo. Že $\vee$ uvodnih določbah nove slovenske ustave, $\vee$ katerih so zapisana in zagotovljena temeljna politična načela in družbene vrednote, s katerimi Slovenija opredeljuje svojo državno ureditev, je dobila svoje mesto tudi lokalna samouprava. Ustava RS je s tem Slovenijo uvrstila med države, ki želijo zagotoviti skupne evropske standarde za

28 Na primer realistično stališče, po katerem je namen politike izražati in braniti interese, namen udeležbe državljanov pa je doseči te cilje in zagotoviti optimalne rezultate z minimalnimi stroški. Drugo stališče je povsem nasprotno. Po njem je demokracija proces, ki potrebuje maksimalno udeležbo državljanov. Tretje stališče temelji na zahtevi izključenih skupin, da se vključijo v procese odločanja. Zagovorniki posvetovalne demokracije pa želijo, da državljani lahko vzpostavijo razmerja s političnimi institucijami, tudi na neinstitucionalen način. Prav tam, str. 4--5.

29 Tako kot druge države članice SE je tudi Slovenija pripravila uradni dokument o strukturi in dejavnosti njene lokalne samouprave, ki ga je CDLR potrdil leta 1997. Služba (zdaj Urad) Vlade RS za lokalno samoupravo redno obvešča generalnega sekretarja SE o zakonskih spremembah in predvidenih aktivnostih na področju lokalne samouprave. Iz prikaza temeljnih dokumentov in usmeritev SE na področju lokalne in regionalne samouprave $v$ prvem delu prispevka je razvidno, da bo treba $v$ slovenski lokalni samoupravi opraviti še veliko zakonodajnega in strokovnega dela. 


\section{Stane Vlaj}

\section{Lokalna in regionalna samouprava $v$ Evropi in pri nas}

opredeljevanje in varovanje pravic lokalnih oblasti, ki so za državljane najbližja raven uprave in jim omogočajo učinkovito udeležbo pri oblikovanju odločitev, nanašajočih se na njihovo vsakdanje okolje.

Reforma slovenske lokalne samouprave vsebuje pet sestavin: funkcionalno, teritorialno, organizacijsko, finančno-materialno in pravno. ${ }^{\mathbf{3 0}}$

Nobena od naštetih sestavin lokalne samouprave v Sloveniji še ni v celoti uresničena. Pri tem je treba ugotoviti, da je bil preveč poudarjen teritorialni vidik, premalo pa funkcionalni, regionalni in finančni vidik. Vlada RS je julija 2001 sprejela Izhodišča in predloge za nadaljnji razvoj lokalne samouprave $v$ RS. Gre za strateški dokument Vlade RS za nadaljevanje reforme lokalne samouprave, ki je nastal tudi na podlagi poročila in priporočila 89. Kongresa lokalnih in regionalnih oblasti Evrope glede stanja na področju lokalne in regionalne demokracije v Sloveniji (junij 2001).

Sprejeta je bila vrsta zakonov in drugih predpisov, ki urejajo lokalno samoupravo oziroma se nanašajo nanjo. Ustavna načela konkretizirata predvsem Zakon o lokalni samoupravi (ZLS) in Zakon o financiranju občin (ZFO). ZLS je občinam v izvirno pristojnost dodelil naloge, ki so bistvenega pomena za življenje in delo njenega prebivalstva in se lahko $v$ občini uresničujejo in obvladujejo racionalneje in učinkoviteje kot z državno oblastjo. ZFO pa temelji na načelu, da se občine financirajo predvsem iz lastnih virov, pa tudi iz sredstev državnega proračuna, ki so jim dodeljena $\vee$ obliki finančne izravnave in dotacij za naložbe zaradi izravnavanja potreb financiranja občinskih nalog in njihovih lastnih zmožnosti. Zakon o javnih financah ureja tudi zgradbo, pripravo in uresničevanje proračunov lokalnih skupnosti, upravljanje premoženja lokalnih skupnosti, njihovo zadolževanje, jamstva, upravljanje dolgov, račune in proračunski nadzor. Posamezne sestavine lokalne samouprave ureja še cela vrsta zakonov, med katerimi je treba omeniti Zakon o ustanovitvi občin ter o določitvi njihovih območij, Zakon o referendumu za ustanovitev občin in Zakon o postopku za ustanovitev občin ter za določitev njihovih območij (ZPUODO), $\checkmark$ skladu s katerima so bile ustanovljene občine in določeno oziroma spremenjeno njihovo območje. Lokalne volitve so urejene v Zakonu o lokalnih volitvah (ZLV).

30 Pri funkcionalni sestavini gre za prerazporeditev pristojnosti med državo in občinami kot temeljnimi samoupravnimi lokalnimi skupnostmi, za uresničevanje načela subsidiarnosti $s$ procesom decentralizacije, ki se je začel. Pri ozemeljski sestavini gre za ustanavljanje novih občin, ki so nadomestile nekdanje komune. Iz 62 komun je nastalo v letu 1994147 novih občin, v letu 1998 še 45 in v letu 2002 še ena občina. Skupaj imamo danes v Sloveniji 193 občin, ki niso vse oblikovane $v$ skladu z zakonskimi merili. Polovica jih ima manj kot 5000 prebivalcev, vse pa tudi nimajo popolne osnovne šole, zdravstvenega doma ali zdravstvene postaje, banke, pošte, ustreznih prostorov za delo občinskih organov itd. Pri organizacijski sestavini gre za novi razpored organizacije oblasti v občini, ki ga sestavljajo organi (neposredno izvoljena občinski svet in župan, nadzorni odbor) in oblike neposrednega sodelovanja državljanov pri odločanju $v$ občini (zbori občanov, referendumi in državljanska pobuda). Pri finančno-materialni sestavini gre za uresničevanje načel sorazmernosti sredstev z nalogami lokalnih skupnosti, solidarnosti do razvojno šibkejših občin, pravice do lastnih virov lokalnih skupnosti itd. Pri pravni sestavini pa gre za položaj občine kot pravne osebe javnega prava in njeno vključenost v celotni pravni sistem RS. 


\section{Lokalna in regionalna samouprava $v$ Evropi in pri nas}

Razmejitev pristojnosti med državo in občinami urejajo Zakon o prevzemu državnih funkcij, ki so jih do 31. 12. 1994 opravljali organi občin in področni zakoni (npr. Zakon o varstvu okolja, Zakon o urejanju prostora, Zakon o geodetski službi). Državni nadzor nad zakonitostjo dela občinskih organov poleg ZLS urejata še Zakon o državni upravi (ZU) in Zakon o vladi.

Zakon o inšpekcijskem nadzoru se z izjemo določb o organizaciji uporablja tudi za inšpekcijski nadzor, ki ga izvajajo organi lokalnih skupnosti. Zakon o javnih uslužbencih celovito ureja sistem javnih uslužbencev $v$ državnih organih in upravah lokalnih skupnosti ter posebnosti delovnih razmerij javnih uslužbencev $\vee$ državnih organih in upravah lokalnih skupnosti. Zakon o javnih agencijah ureja javno agencijo kot statusno obliko osebe javnega prava. Ustanovi jo lahko tudi samoupravna lokalna skupnost ali zveza samoupravnih lokalnih skupnosti. Zakon o gospodarskih javnih službah določa način in oblike izvajanja gospodarskih javnih služb. Z njimi se zagotavljajo materialne javne dobrine kot proizvodi in storitve, katerih trajno in nemoteno proizvajanje $v$ javnem interesu zagotavlja Republika Slovenija oziroma občina ali druga lokalna skupnost zaradi zadovoljevanja javnih potreb, kadar jih ni mogoče zagotavljati na trgu. Zakon o sistemu plač v javnem sektorju (ZSPJS) ureja sistem plač funkcionarjev in javnih uslužbencev $v$ javnem sektorju ${ }^{\mathbf{3 1}}$.

Občina ureja zadeve iz svoje pristojnosti s svojimi splošnimi akti oziroma predpisi. Tako so za pravno urejanje lokalne samouprave pomembni predvsem statuti občin, ki vsebujejo temeljna načela za organizacijo in delovanje občine, oblikovanje in pristojnosti občinskih organov, organizacijo občinske uprave, sodelovanje občanov pri sprejemanju odločitev in druge statusne določbe. Pomembni so tudi poslovniki občinskih svetov in nadzornih odborov ter odloki o ustanovitvi, organizaciji in delovnem področju organov občinske uprave. Z odloki, odredbami, pravilniki in navodili občine določajo splošna pravna pravila, na podlagi katerih opravljajo naloge iz svoje ter zadeve iz prenesene pristojnosti, če je tako določeno z zakonom.

Uresničevanje ustavnih načel in določb o lokalni samoupravi, spoštovanje načel ratificirane MELLS in vključitev Slovenije v EU zahtevajo uskladitev in nadaljnje dopolnjevanje veljavnih predpisov in tudi novo pravno urejanje lokalne samouprave. $Z$ zakoni bo treba pravno urediti še pokrajine, medobčinsko sodelovanje ter vlogo in položaj glavnega mesta države.

$\checkmark$ področni zakonodaji je treba $v$ skladu $z$ načelom subsidiarnosti razmejiti naloge med državo in lokalno samoupravo (občine, pokrajine) ter prenesti nekatere državne naloge $v$ opravljanje občinam.

31 Javni sektor po tem zakonu sestavljajo državni organi in samoupravne lokalne skupnosti, javne agencije, javni skladi, javni zavodi, javni gospodarski zavodi ter druge osebe javnega prava, ki so posredni uporabniki državnega proračuna ali proračuna lokalne skupnosti. Javna podjetja in gospodarske družbe, $v$ katerih ima večinski delež oziroma prevladujoč vpliv država ali lokalna skupnost, niso del javnega sektorja po tem zakonu. 


\section{Stane Vlaj}

\section{Lokalna in regionalna samouprava $v$ Evropi in pri nas}

V Komisiji za ustavna vprašanja Državnega zbora je bil podprt tudi vladni predlog za spremembo Ustave RS, ki se nanaša na uvedbo pokrajin kot obvezne druge ravni lokalne samouprave $v$ RS, prenos državnih nalog na pokrajine brez njihovega predhodnega soglasja ter na opravljanje državnih upravnih nalog ${ }^{32}$ tudi $\vee$ občinah in pokrajinah. Pričakovati je, da bodo te spremembe sprejete v letu 2004.

$\checkmark$ nadaljevanje reforme je treba vključiti tudi najnovejša družboslovna spoznanja, ki presegajo lokalno zaprtost, kakršno utrjuje naš pravni red. Gre za prehod od "prostora krajev" k "prostoru tokov", razliko med "starim" (zaprtim) in "novim" (odprtim) lokalizmom, "novi regionalizem», "teledemokracijo", ki spreminja dosedanji pomen neposredne in posredne demokracije, "novo politično kulturo «, ki kaže na izpodkopavanje toge, hierarhične teritorialne organiziranosti, slabitev vloge političnih strank ter krepitev vloge mnoštva raznih (pod)skupin, ki presegajo lokalne in nacionalno-državne okvire. Ta spoznanja nakazujejo dolgoročno perspektivo nastajanja globalne civilne družbe. ${ }^{33}$

\section{Regionalizacija Slovenije}

Slovenija sodi v krog držav, ki imajo vse možnosti za dvonivojsko lokalno samoupravo - gospodarske, geografske, upravno-politične, zgodovinske idr. Razvoj lokalne samouprave in pretirana centralizacija nalog $v$ državi kažeta na potrebo po krepitvi moči občine $v$ razmerju do države preko pokrajine ${ }^{\mathbf{3 4}}$ kot druge ravni lokalne samouprave $\vee$ Sloveniji. Pokrajine naj bi zapolnile vrzel med majhnimi občinami in državo in blažile sedanjo preveliko urejevalno in dejansko moč države $v$ odnosu do šibkih občin. Povezovale naj bi občine zaradi učinkovitejšega urejanja in izpolnjevanja potreb državljanov in gospodarstva, ki presegajo zmogljivosti posamezne občine.

$\checkmark$ unitarni državi, kot je Slovenija, je regionalizacija pravzaprav način za vzpostavitev vmesne stopnje med lokalnimi skupnostmi in državo. Pokrajina naj bi $v$ medsebojni povezanosti opravljala državne naloge, ki jih je treba opravljati v pokraji$\mathrm{ni}$, in samoupravne naloge lokalnega pomena, ki so odsev procesov $\mathrm{v}$ tem prostoru. Pokrajine bodo opravljale naloge, ki presegajo zmogljivosti majhnih občin, predvsem pa zadeve, ki jih bo država prenesla $v$ njihovo izvirno in preneseno pristojnost in odgovornost. Pokrajine so nujno potrebna struktura, ki bo zapolnila vrzel med (pre)majhnimi občinami in državo ter bo primerno mesto za uresničevanje načela subsidiarnosti oziroma za nujno potrebno decentralizacijo in demokratizacijo naše države. To nam narekujejo predvsem domače razmere in razlogi, pa tudi primerljivost

32 Zdaj državne upravne zadeve, npr. izdajanje različnih dovoljenj in drugih dokumentov, opravlja 58 upravnih enot kot oblik teritorializirane državne uprave.

33 Prim. Mlinar, Zdravko, "Globalizacija» ali getoizacija lokalne demokracije? Teorija in praksa, št. $3 / 00$.

34 Pri tem moramo opozoriti, da je mogoče naše pokrajine primerjati npr. s provincami $v$ Italiji, okrožji na Danskem, landkreisi v ZRN ali departmaji v Franciji, ne pa z evropskimi regijami. 


\section{Lokalna in regionalna samouprava $v$ Evropi in pri nas}

z evropskimi kriteriji in standardi, ki jih vsebujejo ratificirana MELLS in drugi dokumenti SE in EU.

Pri regiji (pokrajini) gre za vmesni prostor med državo in občinami, v katerem se pojavljajo aktualne potrebe, kot so gradnja in vzdrževanje lokalnih cest regionalnega pomena, oskrba z vodo in energijo idr., ki jih je treba upoštevati in zadovoljevati. $V$ tem vmesnem prostoru se kopičijo problemi, ki temeljijo na eni strani na interesih države, na drugi strani pa gre za interese lokalnega pomena. Ta prostor lahko označujemo kot regijo, ne glede na to, kakšno ime lahko dobi, če ji država prizna določeni upravnosistemski položaj.

Pokrajine so $v$ Sloveniji potrebne tudi zaradi primerljivosti z državami EU in zaradi uspešnejšega kandidiranja za sredstva EU za regionalni razvoj. Strukturni skladi, ki so namenjeni spodbujanju regionalnega razvoja $\vee E U$, bodo pomembni tudi za Slovenijo oziroma njen regionalni razvoj. Potreba po pokrajinah pa se kaže tudi zaradi čezmejnega sodelovanja lokalnih in regionalnih skupnosti.

Pri prizadevanjih za uvedbo pokrajin je treba največjo pozornost posvetiti štirim sklopom vprašanj: kakšne bodo njihove pristojnosti, organizacija in upravljanje, financiranje in premoženje ter na tej podlagi najoptimalnejša razdelitev Slovenije na pokrajine. Največjo strokovno podporo ima model velikih pokrajin, tj. 6 do 8 pokrajin.

\section{Zaključek}

Razvita lokalna samouprava je temelj vsakega demokratičnega sistema. Lokalne skupnosti naj bi opravljale vse tiste javne zadeve, ki se učinkoviteje in racionalneje ter bližje državljanom upravljajo na lokalni ravni. Organi in uprave lokalnih skupnosti imajo pri tem odločilno vlogo. Iz dokumentov SE lahko povzamemo, da bodo $\vee$ novem stoletju na področju lokalne in regionalne demokracije $\vee$ Evropi $\vee$ ospredju naslednji cilji in vrednote:

- varstvo človekovih pravic in uveljavljanje vseh vrst demokracije;

- povečana participacija državljanov v lokalnem in regionalnem javnem življenju; še zlasti je treba zagotoviti povečanje udeležbe mladih in žensk v organih lokalnih in regionalnih skupnosti;

- čezmejno sodelovanje lokalnih in regionalnih skupnosti, še zlasti na področju kulture, medsebojnega spoznavanja in učenja;

- uveljavljanje načela subsidiarnosti in s tem povezane regionalizacije držav;

- na partnerstvu temelječ in skupen pristop vseh akterjev in s tem krepitev demokratične strukture in duha evropskih integracijskih procesov na vseh ravneh oblasti;

- nepogrešljiva vloga lokalnih in regionalnih skupnosti pri uresničevanju prava EU na poddržavni ravni. 


\section{Stane Vlaj}

\section{Lokalna in regionalna samouprava $v$ Evropi in pri nas}

SE se zaveda različnosti sistemov lokalne samouprave $v$ evropskih državah, zato bo podpiral reforme, ki se nanašajo na decentralizacijo, pomagal pri razvoju učinkovitih lokalnih demokratičnih institucij (na občinskih in višjih oziroma regionalnih ravneh), krepil zmožnost delovanja lokalnih skupnosti in njihovih združenj ter razvijal oblike usposabljanja, ki naj da lokalno izvoljenim predstavnikom in osebju v lokalnih upravah znanje in veščine ter jih usposobi za zagotavljanje storitev, ki bodo v skladu s pričakovanji lokalnega prebivalstva.

Lokalna demokracija $\vee$ Evropi je $\vee$ zadnjih desetih letih dosegla velik napredek. Gre za kontinuiran in dinamičen proces, $v$ katerem lokalne oblasti dobivajo nove pristojnosti in odgovornosti. Število lokalnih pristojnosti vsepovsod narašča, usmeritve $\vee$ lokalnem financiranju pa so vse bolj $\vee$ škodo interesov lokalnih skupnosti. Načelo subsidiarnosti pomeni ravnovesje med pristojnostmi in finančnimi viri lokalnih skupnosti, zahteva pa tudi odgovornost lokalnih in regionalnih oblasti, da poznajo potrebe svojih prebivalcev in temu ustrezno organizirajo javne službe; poleg tega imajo tudi odgovornost do države.

$\checkmark$ zadnjih nekaj desetletjih so evropske države zaradi skladnosti z interesi evropskih prebivalcev za višjo kakovost življenja preuredile strukturo svojih javnih oblasti z institucionaliziranjem različnih ravni oblasti. Javne zadeve so $v$ precejšnji meri prenesle na lokalno in regionalno samoupravo. $\vee$ večini evropskih držav prenaša država na občine in druge lokalne skupnosti del svojih pristojnosti, kadar ocenjuje, da je na ta način mogoče učinkoviteje uresničevati posamezne zadeve, bolj upoštevati specifičnosti nekega območja ali približati upravo prebivalcem. Lokalne skupnosti opravljajo tudi velik del državne uprave, ki ima pomen za prebivalce teh skupnosti.

Vsepovsod $v$ Evropi se odvija proces decentralizacije ter krepitev demokracije in novega sistema upravljanja, ki zahteva sofisticirane mehanizme dialoga.

Vsak politični sistem ima kakšen način za izražanje potreb in zahtev državljanov in družbenih skupin do oblasti. Gre za različne oblike artikulacije in združevanja interesov. Najbolj temeljna oblika je participacija in dejavnost državljanov z različnimi metodami - od volitev do osebnih stikov, od protestov in neposredne aktivnosti do enostavne politične abstinence. Bolj institucionalizirane oblike artikulacije interesov pa se pojavljajo s socialnimi in političnimi skupinami, ki predstavljajo interese svojih članov. Te skupine se razlikujejo po organizacijskih elementih, finančnih mehanizmih, političnem stilu in klienteli. Med njimi so tudi združenja lokalnih in regionalnih oblasti kot primer institucionalnih interesnih skupin, ki poskušajo legitimno doseči centralno oblast po dostopnih kanalih.

Pri reformah lokalnih skupnosti $\vee$ Evropi in pri nas gre za povezanost teritorialnih sprememb z vsebinskimi vprašanji in še zlasti z dobrim upravljanjem, ki bo v korist prebivalstva. Kdaj sploh so potrebne teritorialne reforme? Kakšen je koncept dobrega upravljanja $\vee$ posamezni državi? Kaj naj se upošteva pri snovanju lokalnih (in regionalnih) skupnosti? Ali so ob ekonomskih vidikih, ki so temeljni, pomembni 
še drugi vidiki oziroma cilji? Ali današnji teritorialni okviri lokalnih skupnosti še ustrezajo? Kako usklajevati pristopa 'od zgoraj navzdol' (državni) in 'od spodaj navzgor' (lokalni, državljanski)? Kako ugotoviti identiteto lokalnih in regionalnih skupnosti? Kako čim bolj upoštevati in obveščati njihove prebivalce pri teritorialnih reformah? Ali imajo državne oblasti jasno izdelano strategijo in cilje razvoja lokalnih in regionalnih skupnosti?

SE poudarja, da gre pri upravljanju za temeljna vprašanja, kot so: centralizacija, decentralizacija, devolucija; učinkovitost in demokratičnost lokalnih in regionalnih oblasti; etični standardi pri delu lokalnih uprav; pomembnost načela subsidiarnosti nove pristojnosti lokalnih in regionalnih oblasti in njihovi stiki s prebivalci; enakovrednost javnih služb - enaki standardi storitev za državljane v vsej državi; partnerstvo med ravnmi oblasti, nacionalna združenja lokalnih skupnosti; demokracija medijev.

Uresničevanje načela subsidiarnosti in decentralizacije je značilnost moderne dobe. Čeprav je vsaka država avtonomna pri odločanju o svoji oblastni strukturi, gre $\checkmark$ zadnjih desetletjih $\vee$ Evropi za naraščajočo decentralizacijo in devolucijo, ki se odvijata $v$ več modelih regionalne samouprave. Ekonomska rast, soobstojni razvoj in kakovostne javne službe se lahko učinkoviteje uveljavljajo, če oblastne institucije niso vsesplošno centralizirane. Razvoj gre $v$ smeri učinkovite in demokratične oblasti na vseh ravneh, pri čemer morata biti vedno $v$ ospredju državljan in kakovost njegovega življenja. To pa je mogoče, če med različnimi ravnmi oblasti in državljani obstajata stalni dialog in partnerstvo.

Evropske integracije vse bolj računajo tudi s poddržavnimi strukturami oblasti v posamezni državi, tj. z lokalnimi in regionalnimi oblastmi. Nanje se najtesneje vežejo vprašanja, ki so povezana z uresničevanjem načel subsidiarnosti, decentralizacije in demokratizacije ter partnerstva in sodelovanja različnih ravni oblasti znotraj držav in $v$ mednarodnih povezavah. Večina evropskih držav se giblje k devoluciji, ustanavljajo se regije ali pa se daje dodatna avtonomija že obstoječim regijam; načelo regionalne samouprave, ki ga prav tako poudarja EU, je povezano s spoštovanjem demokracije in z vidikom večje integracije Evrope.

Regionalizacija v Evropi kaže zelo pestre institucionalne oblike. Ne obstaja pa en model regionalne samouprave, ki bi ga lahko prenesli v vsako državo.

Narašča pomen regij oziroma vmesnih ravni oblasti med centrom in občinsko ravnjo. Te vmesne ravni imajo različen položaj v posameznih državah. Ne glede na to pa gre $v$ vseh primerih za spremenjeno naravo starih držav. Tudi politika EU je odprla vrata za nov scenarij, $v$ katerem regionalne in lokalne oblasti dobivajo podporo za svoje nove zahteve.

Lokalna in (bodoča) pokrajinska samouprava v RS sta sestavni del javne uprave. Imamo 193 občin, ki se zelo razlikujejo med seboj po velikosti teritorija, številu prebivalcev, razvitosti, številu zaposlenih $\vee$ občinskih upravah in kakovosti dela, udeležbi prebivalcev $v$ lokalnem javnem življenju, povezovanju in sodelovanju na horizontalni ravni, dejavnosti $v$ dveh reprezentativnih združenjih občin, čezmejnem 


\section{Stane Vlaj}

\section{Lokalna in regionalna samouprava $v$ Evropi in pri nas}

sodelovanju idr. Več kot polovica občin ne izpolnjuje zakonskih pogojev za ustanovitev. Z upravnega vidika smo dobili neracionalne občine; tudi ni pričakovati, da bi se $\checkmark$ kratkem začele združevati $v$ večje enote. $\vee$ nadaljevanju reforme lokalne samouprave bi bilo treba nameniti veliko pozornost učinkovitosti občin (občinskih organov in občinske uprave), še posebej pa soodvisnosti med velikostjo občine, njeno učinkovitostjo in participacijo državljanov v lokalnem javnem življenju, kriterijem za oblikovanje lokalnih in pokrajinskih skupnosti, analizi sedanjih pristojnosti občin in njihovemu financiranju, nalogam lokalnih skupnosti po vključitvi RS v EU, upravljanju občinskega premoženja in proračuna, lokalnim javnim službam, javni etiki na lokalni ravni ter razmerjem lokalnih skupnosti do države.

Marsikje v Evropi si prizadevajo za združevanje majhnih občin $\vee$ večje enote ali pa močno spodbujajo medsebojno sodelovanje občin. Vse države si prizadevajo za takšno velikost lokalnih in regionalnih skupnosti, ki bo omogočala potrebne finančne in človeške vire za čim kakovostnejše javne storitve za zadovoljevanje sodobnih potreb prebivalcev. Pomembnost teritorija je povsem jasna, pa naj gre za gospodarski, socialni, politični ali upravni vidik. Parametri, ki jih je treba upoštevati pri oblikovanju novih teritorialnih skupnosti, so: velikost (teritorij, prebivalstvo), funkcije (naloge in pristojnosti), avtonomija (razmerja med državnimi oblastmi in lokalno/regionalno samoupravo, fiskalna in funkcionalna soodvisnost) in način delovanja (razmerje med javno in zasebno produkcijo). Ti parametri so medsebojno odvisni. V skandinavskih državah še dodajajo, da so ob finančnih razlogih za reforme, ki naj prinesejo čim zmožnejše lokalne in regionalne skupnosti, zelo pomembni tudi demokratični cilji.

Pripravljene so spremembe Ustave RS, ki naj bi jih sprejel državni zbor v letu 2004. Predlagani novi 143. člen ustave določa, da so pokrajine obvezna druga raven lokalne samouprave, ki jih ustanovi država z zakonom za opravljanje lokalnih zadev širšega pomena in z zakonom določenih nalog regionalnega značaja. Pokrajine naj bi opravljale tudi naloge $v$ imenu in za račun države (državne upravne zadeve). Na ta način bi bila omogočena decentralizacija Slovenije in $s$ tem uresničevanje načela subsidiarnosti. Pri uvedbi pokrajin $\vee$ RS gre za povezanost nove enote teritorialne samouprave (demokracije) z vsebinskimi vprašanji, zlasti z dobrim upravljanjem, ki bo $v$ korist tam živečega prebivalstva.

\section{Literatura in pravni viri}

- Draft report (No. PE 204-739) of 20 April 1993 on local authorities in the political and institutional construction of European Union: the principle of subsidiarity and the Committee of the Regions.

- Council of Europe, Definition and limits of the principle of subsidiarity, Local and regional authorities in Europe, No. 55, Council of Europe Press, 1994.

- The size of municipalities, efficiency and citizen participation, Council of Europe, 1995, Local and Regional authorities in Europe, No. 56. 
- Institutional dialogue between the state, regions, local authorities and their associations, Steering committee on local and regional democracy (CDLR), Strasbourg, 8. april 2002.

- Recommendation Rec (2001) 19 of the Committee of Ministers to member states on the participation of citizens in local public life, 6. december 2001.

- Appendices to the preliminary draft report on the participation of citizens in local public life, Steering Committee on Local and Regional Democracy (CDLR), Strasbourg, 8. november 1999.

- Council of Europe, Local democracy at the dawn of the 21st century, Riga, 3. - 4. maj 2001.

- Congress of Local and Regional Authorities of Europe, Situation of local and regional democracy in Slovenia, Explanatory Memorandum, Recommendation 89 (2001) on the situation of local and regional democracy in Slovenia, Eighth Session, Strasbourg, 29. - 31. maj 2001.

- Helsinki Declaration on Regional Self-Government, Conference of European ministers responsible for local and regional government, 13th Session, Helsinki, 27. - 28. junij 2002.

- Administrative and territorial reforms creating territorial communities or authorities, CDLR, Strasbourg, 7. marec 2002.

- Public ethics at local level, Model initiatives package, CDLR, Strasbourg, 13. januar 2003.

- Poročilo, stališča in predlogi skupine strokovnjakov za regionalizem glede predloga za začetek postopka za spremembo 143. člena ustave, ki ga je vložila v Državnem zboru RS skupina poslancev s prvopodpisanim dr. Cirilom Ribičičem (EPA 708-I), Poročevalec Državnega zbora Republike Slovenije, št. 92/00.

- $\quad$ Izhodišča za nadaljnji razvoj lokalne samouprave v RS - EVA 2001-1525-0006, Ljubljana, 18. 7. 2001.

- Predlog za začetek postopka za spremembo Ustave Republike Slovenije z osnutkom ustavnega zakona - EPA 283-III, Poročevalec Državnega zbora, št. 69/01.

- Mlinar, Zdravko, "Globalizacija» ali getoizacija lokalne demokracije? Teorija in praksa, št. 3/00.

- Izhodišča za nadaljnji razvoj lokalne samouprave v RS - EVA 2001-1525-0006, Ljubljana, 18. 7. 2001.

- Šmidovnik, Janez, Lokalna samouprava, Cankarjeva založba, Ljubljana, 1995.

- Vlaj, Stane, Lokalna samouprava: občine in pokrajine, (Knjižna zbirka Teorija in praksa). Ljubljana: Fakulteta za družbene vede, 1998.

- Vlaj, Stane, Lokalna samouprava s poudarkom na načelu subsidiarnosti. Ljubljana: Visoka upravna šola, 2001.

- Zakon o ratifikaciji Evropske listine lokalne samouprave (MELLS) (Uradni list RS, št. 57/96 Mednarodne pogodbe, št. 15).

- Zakon o lokalni samoupravi - ZLS (Ur. I. RS, št. 72/93, 57/94, 14/95, 26/97, 70/97, 10/98, 74/98, 70/00, 51/02). V zakonodajni proceduri je nov ZLS, ki naj bi bil sprejet v I. 2004.

- Zakon o financiranju občin - ZFO (Ur. I. RS, št. 80/94, 45/97, 56/98).

- Zakon o javnih financah (Ur. I. RS, št. 79/99).

- Zakon o ustanovitvi občin ter o določitvi njihovih območij (Ur. I. RS, št. 60/94, 69/94, 56/98, 75/98, 67/98, 72/98).

- Zakon o referendumu za ustanovitev občin (Ur. I. RS, št. 75/94).

- Zakon o postopku za ustanovitev občin ter za določitev njihovih območij (Ur. I. RS, št. 44/96).

- Zakon o lokalnih volitvah (Ur. I. RS, št. 72/93, 7/94, 33/94, 61/95, 70/95).

- Zakon o prevzemu državnih funkcij, ki so jih do 31. 12. 1994 opravljali organi občin (Ur. I. RS, št. 29/95).

- Zakon o urejanju prostora (ZureP-1) (Ur. I. RS, št. 110/02).

- Zakon o geodetski dejavnosti (Ur. I. RS, št. 8/00). 
Stane Vlaj

Lokalna in regionalna samouprava $v$ Evropi in pri nas

- 90 področnih zakonov - Katalog pristojnosti občin, Služba Vlade RS za lokalno samoupravo, Ljubljana, 1998.

- Zakon o državni upravi (Ur. I. RS, št. 52/02).

- Zakon o Vladi Republike Slovenije, (Ur. I. RS, št. 4/93, 71/94, 23/96, 47/97, 23/99, 119/00).

- Zakon o inšpekcijskem nadzoru (Ur. I. RS, št. 56/02).

- Zakon o javnih uslužbencih (ZJU) (Ur. I. RS. št. 56/02).

- Zakon o javnih agencijah (ZJA) (Ur. I. RS, št. 52/02).

- Zakon o gospodarskih javnih službah (Ur. I. RS, št. 32/93).

Dr. Stane Vlaj je docent na Fakulteti za upravo in direktor inštituta za lokalno samoupravo. Bil je predstojnik Službe Vlade RS za reformo lokalne samouprave in deset let predstavljal Slovenijo $v$ Vodilnem odboru SE za lokalno in regionalno demokracijo.

\section{SUMMARY}

\section{Local and Regional Self-Government in Europe and in Slovenia}

Present-day local democracy in Europe is characterised by two things: general consent on a group of general values and principles, and a large diversity of institutions and practices. The European Charter of Local SelfGovernment (ECLS) derives its general principles of local democracy from the historical experience of the countries and transforms them into a general source and framework. The principles of ECLS can be implemented in different institutional forms. Local democracy is one of the pillars of democracy in Europe: but the principle of subsidiarity is always at the forefront, when the creation of a safe and stable Europe is discussed. The implementation of the principle of subsidiarity is a decentralisation of public matters or competence to the most suitable level, starting with the municipality and indicates the level of democracy in a particular state. Local democracy is of vital importance for a democratic system and represents a constitutive element of a state.

The increasing decentralisation and devolution reflect a generally present belief that economic growth, co-existent development, quality public services and full democratic participation are more efficient when the institutions of authority are not generally centralised.

In the democratic states, the goal of local and regional authorities and of the state itself is to promote the implementation of democracy and to ensure the best possible response to the people's needs. For this purpose, there should exist cooperation between different levels of authority and between 
them and the citizens. This allows the establishment of the required balance between all participants in the dialogue. If a political system wishes to achieve the desired results, it should include in the decision-making process all those concerned by a particular decision.

When reforming the local self-government in Slovenia the functional, financial and regional components were particularly neglected. Therefore the extremes occurred, such as: establishment of large and rather small municipalities, the establishment of municipalities with narrow local competence from previously overburdened municipalities etc. The Constitution of the Republic of Slovenia in 2004 will be amended. The new Article 143 will be the basis for establishing regions as a secondary level of local self-government in Slovenia. Regions should be more efficient partners to the Structural Funds and in crossborder co-operation as well. 